\title{
An evaluation of the efficiency of beekeeping enterprises in Hatay province with data envelopment analysis
}

\author{
Ufuk KAYA ${ }^{1, a, \bigotimes}$, İsmayil Safa GÜRCAN ${ }^{2, b}$ \\ ${ }^{1}$ Hatay Mustafa Kemal University, Faculty of Veterinary Medicine, Department of Biostatistics, Hatay; ${ }^{2}$ Ankara University, Faculty \\ of Veterinary Medicine, Department of Biostatistics, Ankara, Turkey \\ ${ }^{\mathrm{a} O R C I D: 0000-0002-4805-0993 ; ~}{ }^{\mathrm{b} O R C I D:}$ 0000-0002-0738-1518

Corresponding author: u.kaya @ mku.edu.tr
Received date: 19.06 .2020 - Accepted date: 13.10 .2020

\begin{abstract}
This study was aimed to determine technical and economic efficiency in beekeeping enterprises and to reveal the factors effecting the efficiency scores. The material of the current study consisted of the data obtained from 46 enterprises in Hatay province. Efficiency scores for technical and economical properties were determined with data envelopment analysis. The truncated regression model was used to determine the factors effecting the efficiency scores. The efficiency scores for technical and economical properties were calculated as 0.97 and 0.94 , respectively. The results showed that 'experience', 'race of bee', 'education level' and 'number of colony' variables were found to be statistically significant factors on efficiency of technical properties. No significant factors were found on efficiency of economic properties. In conclusion, it was revealed what conditions should be had in terms of technical and economical properties to be performed an efficient beekeeping activity in Hatay province.
\end{abstract}

Keywords: Beekeeping, data envelopment analysis, efficiency, truncated regression model.

\section{Hatay ili arıcılık işletmelerinin etkinliklerinin veri zarflama analizi ile değerlendirilmesi}

Özet: Bu çalışmada arıcılık işletmelerinde teknik ve ekonomik etkinliğin belirlenmesi, etkinlik skorlarına etki eden faktörlerin ortaya konulması amaçlanmıştır. Çalışmanın materyalini, Hatay ilindeki 46 adet arıcılık işletmesinden elde edilen veriler oluşturmaktadır. Teknik ve ekonomik özellikler açısından işletmelerin etkinlik skorları veri zarflama analizi ile belirlenmiştir. Etkinlik skorları üzerine etki eden faktörlerin belirlenmesi amacıyla kesilmiş regresyon modelinden yararlanılmıştır. Teknik ve ekonomik özellikler bakımından etkinlik skorları sırasıyla, 0,97 ve 0,94 bulunmuştur. Teknik özelliklerin etkinlik skorları üzerine, 'deneyim', 'arı 1rk1', 'eğitim seviyesi' ve 'koloni sayısı' parametreleri istatistiksel olarak anlamlı faktörler olarak tespit edilmiştir. Ekonomik özelliklerin etkinlik skorları üzerine, istatistiksel olarak anlamlı bir faktör bulunmamıştır. Sonuç olarak, Hatay ilinde etkin bir arıcılık faaliyeti yapılabilmesi için teknik ve ekonomik özellikler bakımından hangi şartlara sahip olunması gerektiği ortaya konulmuştur.

Anahtar sözcükler: Arıcılık, etkinlik, kesilmiş regresyon modeli, veri zarflama analizi.

\section{Introduction}

Beekeeping is a sub-sector of livestock, in which products with great importance for human health such as pollen, propolis, royal jelly, and especially honey, which provide economic value and profit, are produced by blending plants, honeybee, and labor (13). Compared to other livestock sectors, it holds advantages such as requiring less manpower and little dependence on the land $(13,19,36)$. All over the world, beekeeping is a common activity and it keeps developing each year. According to FAO data in 2017, China was ranked first in terms of honey production, beehive number, and honey yield per hive. As for Turkey, although it was ranked second in terms of the total number of beehives and honey production, it was ranked quite at the bottom among the leading countries in honey yield per hive (17). Thanks to being rich in plants, Turkey is able to produce various types of honey and honeybee products $(16,31)$. However, due to the factors such as breeding wrong races, mistaken struggles against honeybee pests and diseases, lack of knowledge about colony management, Turkey cannot fully reflect its potential (11). At this point, it is quite important for the beekeeping sector in Turkey to have modern enterprises which work efficiently and effectively (20). 
In Hatay province in 2017 , the total number of hives, number of beekeeping enterprises, and honey yield per hive $(\mathrm{kg})$ were reported as 95943,554 , and $10.58 \mathrm{~kg}$, respectively (35).

Performing this study in the field of beekeeping and examining the beekeeping enterprises in detail was very important for the veterinary medicine and beekeeping sector. In this study, it was aimed to determine the activities of beekeeping enterprises both technically and economically using data envelopment analysis. Furthermore, influential factors on efficiency scores of beekeeping enterprises were determined with a truncated regression model.

\section{Materials and Methods}

The study material was consisted of information gathered from 46 enterprises, which were registered under the Ministry of Agriculture and Forestry and Hatay Beekeeping Association and operate actively. The sample size was determined using a stratified random sampling method (33). In the analysis, demographic information about the enterprise and its owner, technical properties of the enterprises included in the study, bee feeding cost, auxiliary material cost, marketing and packaging cost, transportation and hive accommodation cost, drug cost, maintenance-repair cost, and other cost were used as inputs, and the income from honey sales, incidental income, and government supports were used as outputs (3, $6,13,16)$.

Data Envelopment Analysis (DEA) was aimed to measure the efficiency of decision making units by using present similar inputs and outputs. Through this analysis, efficient and non-efficient units were determined and solutions were developed to turn non-efficient units into efficient ones. At the same time, in order to become efficient, non-efficient decision making units try to assimilate themselves to the clusters consisting of efficient decision making units that were called the reference set $(21,30)$.

A certain efficient frontier is formed with DEA, and thus the distance of decision making units can be determined. The decision making units which are formed as a result of DEA and which have the function equal to 1 in value are called "efficient", and those which have a function smaller than 1 in value are called "non-efficient" decision making units (30). The efficiency of decision making unit in DEA is obtained as follows;

$$
\begin{array}{ll}
\frac{\sum_{r=1}^{S} u_{r} y_{r 0}}{\sum_{i=1}^{m} v_{i} x_{i 0}} & \frac{\sum_{r=1}^{S} u_{r} y_{r j}}{\sum_{i=1}^{m} v_{i} x_{i j}} \leq 1 \\
u_{r} \geq 0 & , \quad v_{i} \geq 0
\end{array}
$$

Here "s" stands for the number of output, "m" stands for the number of input, and " $\mathrm{j}$ " stands for decision making unit (24). In addition to these; $x_{i j}$ : stands for $i$. the input amount used by j. decision making units, $\mathrm{y}_{\mathrm{rj}}$ : stands for $\mathrm{r}$. the output amount used by $\mathrm{j}$. decision making units, $\mathrm{u}_{\mathrm{r}}$ : stands for the weight given to r. output by decision making unit, $v_{\mathrm{i}}$ : stands for the weight given to $\mathrm{i}$. input by decision making units $(8,10)$.

BCC (Banker, Charnes, Cooper) model, developed by Banker, Charnes and Cooper in 1984, is defined as the DEA model, which has been generated because the technical efficiency and scale efficiency are confused with each other in CCR (Charnes, Cooper, Rhodes) model, and whose hypothesis variable return to scale, which is defined as the imbalance between the increase in the input amount and the increase in the output amount in a decision making unit is valid $(5,8,9)$. It can be analyzed in two different forms, namely input or output oriented models. The aim of input oriented models is to minimize the input variables in order to produce a certain output in the most effective way $(10,30,34)$.

DEA produces no results as to why non-efficient enterprises are non-efficient. For this reason, a truncated regression model was used to determine which factors have impacts on the efficiency in the second stage. The truncated regression model was used to solve the problem of bias due to correlation between input, output variables, and factors, to reduce sampling errors compared to other models, and to predict stronger confidence intervals (18, $22,32)$.

Within the scope of this study, primarily, descriptive statistics of all collected variables were calculated. DEA was used to calculate the efficiency of enterprises. In the study, input oriented BCC model was used as it is more flexible compared to CCR model, for its ease of interpretation, as it is the most suitable model to apply for beekeeping, and as it is field-oriented. In the study, statistic package programs were used such as SPSS 14.01 (License Number: 9869264) for descriptive statistics, MaxDEA 7 Basic for the determination of efficiency scores as a result of data envelopment analysis and Stata 12/MP4 (Licence Number: 50120500264) for the determination of factors effecting the efficiency scores.

\section{Results}

The average colony number of all enterprises included in the study was 188 . It was found that the enterprise owners were an average of 20.33 years of experience, $67.4 \%$ of them had only primary education, $73.9 \%$ of them worked with crossbreed bee races, $32.6 \%$ of them saved records of their enterprises and $26.1 \%$ of them changed the queen in beehives in a time longer than 2 years.

The annual means for the input variables for the technical properties of beekeeping enterprises were calculated as follows: 185 beehives, 65 kilograms of beeswax to process, 20 sacks of sugar, 2.5 cans of sugar syrup, 1 staff and 50 cans. The annual means for the output 
variables were calculated as 1215 kilograms of honey and 4 kilograms of pollen produced in a year.

The target values for technical properties of beekeeping enterprises according to the input oriented BCC model were shown in Table 1. In the study, 40 of these beekeeping enterprises (87\%) were found as efficient. The average efficiency value was calculated as 0.97. Among the efficient enterprises, the ones to give the most number of references (11 references) were enterprises numbered 7 and 32 (Table 5). Enterprises, whose efficiency values are below 1 , were defined as nonefficient enterprises. These enterprises had to take efficient enterprises as a reference to become efficient. For instance, in order for the enterprise numbered 11 to become efficient, it needed to take enterprises numbered $1,15,17$, and 28 as references (Table 5). Accordingly, enterprise numbered 11 could become efficient by reducing the number of hives by 5 , the amount of processed beeswax by $50 \mathrm{~kg}$, the sugar used by approximately half a sack, the number of staff by 2 , the number of packages by 24 , and by increasing the pollen production by $5 \mathrm{~kg}$.

The annual means of input variables for the economic properties of beekeeping enterprises were calculated as follows: 3476.48 Turkish Lira (£) for bee feeding cost, $1069.89 €$ for auxiliary material cost, 597.72 € for marketing and packaging cost, $3704.35 £$ for transportation and hive accommodation cost, $725 €$ for drug cost, 1661.52 for other cost and $563.04 €$ for maintenance-repair cost. As for output variables, they were calculated as follows: $1746.74 €$ as government support, 30804.13 $€$ as honey sales income, and 1006.30 as incidental income $(1 \mathrm{USD}=3.8466 £$ in December, 2017).

Table 1. Target values of technical properties of non-efficient enterprises.

\begin{tabular}{ccccccccccc}
\hline & & \multicolumn{4}{c}{ Input variables } & \multicolumn{3}{c}{ Output variables } \\
\cline { 3 - 9 } $\begin{array}{c}\text { Enterprise } \\
\text { number }\end{array}$ & $\begin{array}{c}\text { Efficiency } \\
\text { score }\end{array}$ & Beehives & Beeswax & Sugar & $\begin{array}{c}\text { Sugar } \\
\text { syrup }\end{array}$ & Staff & Cans & Honey & Pollen \\
11 & 0.98 & -5 & -50 & -0.5 & 0 & -2 & -24 & 0 & +5.31 \\
16 & 0.58 & -118 & -21 & -13 & -9 & -1 & -61 & 0 & 0 \\
24 & 0.66 & -58 & -15 & -1.5 & -2 & -1 & -18 & 0 & +1.77 \\
29 & 0.92 & -53 & -84 & -1 & 0 & -1 & -5 & 0 & 0 \\
36 & 0.64 & -140 & -30 & -3.5 & -1 & -1 & -14 & 0 & +1.85 \\
44 & 0.92 & -74 & -45 & -1 & 0 & -1 & -4 & 0 & 0 \\
\hline
\end{tabular}

Table 2. Target values of economical properties of non-efficient enterprises (€/Year).

\begin{tabular}{|c|c|c|c|c|c|c|c|c|c|c|c|}
\hline \multirow[b]{2}{*}{ 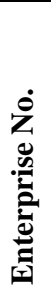 } & \multirow[b]{2}{*}{ 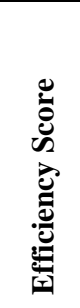 } & \multicolumn{7}{|c|}{ Input variables } & \multicolumn{3}{|c|}{ Output variables } \\
\hline & & 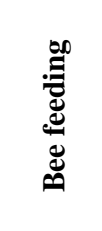 & 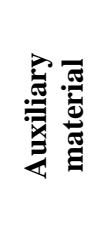 & 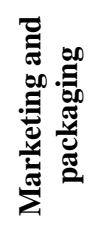 & 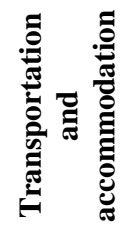 & $\stackrel{+\infty}{E}$ & 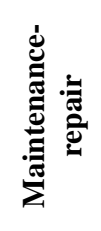 & 爮 & 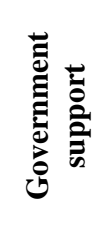 & 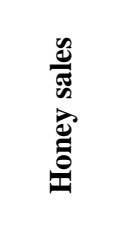 & 苞 \\
\hline 11 & 0.90 & -5071 & -1226 & -614 & -2615 & -143 & -1352 & -33 & +1259 & 0 & +131 \\
\hline 12 & 0.69 & -493 & -218 & -156 & -62 & -467 & -438 & -116 & +749 & 0 & +74 \\
\hline 13 & 0.95 & -90 & -39 & -171 & -20 & -15 & -165 & -10 & +1181 & 0 & +329 \\
\hline 14 & 0.58 & -1334 & -683 & -875 & -2117 & -207 & -415 & -215 & 0 & +7360 & 0 \\
\hline 16 & 0.62 & -2811 & -1642 & -267 & -18000 & -381 & -2935 & -198 & 0 & 0 & +3302 \\
\hline 19 & 0.88 & -294 & -79 & -403 & -2141 & -1250 & -1536 & -42 & 0 & +24884 & +1102 \\
\hline 20 & 0.76 & -536 & -38 & -758 & -644 & -120 & -93 & -60 & 0 & +5250 & +538 \\
\hline 21 & 0.79 & -1082 & -128 & -763 & -373 & -227 & -3962 & -107 & 0 & +7195 & +500 \\
\hline 34 & 0.89 & -728 & -62 & -47 & -127 & -32 & -62 & -78 & 0 & 0 & +466 \\
\hline 37 & 0.77 & -821 & -678 & -277 & -914 & -213 & -473 & -23 & 0 & +4213 & +1507 \\
\hline 38 & 0.98 & -147 & -2 & -72 & -1477 & -6 & -489 & -56 & +10 & 0 & 0 \\
\hline 39 & 0.80 & -357 & -48 & -83 & -3322 & -89 & -149 & -378 & +148 & 0 & +764 \\
\hline 40 & 0.95 & -118 & -5 & -106 & -71 & -190 & -55 & -7 & 0 & 0 & +573 \\
\hline 43 & 0.87 & -334 & -13 & -19 & -1767 & -590 & -47 & -20 & 0 & +4130 & +1089 \\
\hline 45 & 0.84 & -449 & -98 & -69 & -441 & -512 & -163 & -573 & 0 & 0 & +486 \\
\hline
\end{tabular}


Table 3. Parameters effecting the efficiency scores of technical properties.

\begin{tabular}{cccccc}
\hline Parameters & Coefficient & Std. Error & Z & P & 95\% CI \\
\hline Experience & 0.0022 & 0.0009 & 2.41 & 0.016 & $0.0004-0.0039$ \\
Race of bee & -0.691 & 0.027 & -25.21 & $<0.001$ & $(-0.745)-(-0.637)$ \\
Education level & 0.375 & 0.010 & 35.6 & $<0.001$ & $0.354-0.396$ \\
Number of colony & 0.0053 & 0.0001 & 32.47 & $<0.001$ & $0.0050-0.0056$ \\
\hline
\end{tabular}

Table 4. Parameters effecting the efficiency scores of economical properties.

\begin{tabular}{cccccc}
\hline Parameters & Coefficient & Std. Error & $\mathbf{Z}$ & $\mathbf{P}$ & $\mathbf{9 5 \%}$ CI \\
\hline Experience & 0.006 & 0.005 & 1.02 & 0.306 & $-0.005-0.017$ \\
Race of bee & -0.156 & 0.118 & -1.31 & 0.189 & $-0.389-0.076$ \\
Education level & -0.066 & 0.094 & -0.70 & 0.482 & $-0.251-0.118$ \\
Number of colony & -0.0011 & 0.0006 & -1.72 & 0.086 & $-0.0023-0.0001$ \\
Record-keeping status & 0.058 & 0.096 & 0.60 & 0.552 & $-0.132-0.248$ \\
Frequency of changing queen & -0.159 & 0.086 & -1.83 & 0.067 & $-0.328-0.011$ \\
\hline
\end{tabular}

Tablo 5. Reference sets for technical and economical properties.

\begin{tabular}{|c|c|c|c|c|c|}
\hline $\begin{array}{l}\text { Enterprise } \\
\text { number }\end{array}$ & $\begin{array}{l}\text { Technical } \\
\text { properties }\end{array}$ & $\begin{array}{c}\text { Economical } \\
\text { properties }\end{array}$ & $\begin{array}{c}\text { Enterprise } \\
\text { number }\end{array}$ & $\begin{array}{r}\text { Technical } \\
\text { properties }\end{array}$ & $\begin{array}{c}\text { Economical } \\
\text { properties }\end{array}$ \\
\hline 1 & - & - & 24 & $1,10,27,32,45$ & - \\
\hline 2 & - & - & 25 & - & - \\
\hline 3 & - & - & 26 & - & - \\
\hline 4 & - & - & 27 & - & - \\
\hline 5 & - & - & 28 & - & - \\
\hline 6 & - & - & 29 & $9,17,32$ & - \\
\hline 7 & - & - & 30 & - & - \\
\hline 8 & - & - & 31 & - & - \\
\hline 9 & - & - & 32 & - & - \\
\hline 10 & - & - & 33 & - & - \\
\hline 11 & $1,15,17,28$ & $29,33,46$ & 34 & - & $1,7,9,23,27,32,33$ \\
\hline 12 & - & $5,7,27,32,41$ & 35 & - & - \\
\hline 13 & - & $1,5,7,27,32,46$ & 36 & $1,9,12,17,32$ & - \\
\hline 14 & - & $1,3,4,17,23,32$ & 37 & - & $30,31,32$ \\
\hline 15 & - & - & 38 & - & $23,33,41$ \\
\hline 16 & $7,15,17,28,45$ & $1,3,4,17,32,46$ & 39 & - & $4,18,31,32,33$ \\
\hline 17 & - & - & 40 & - & $18,23,24,30,41,42$ \\
\hline 18 & - & - & 41 & - & - \\
\hline 19 & - & $32,36,44,46$ & 42 & - & - \\
\hline 20 & - & $23,24,28,30,36$ & 43 & - & $18,30,32,36,41,42$ \\
\hline 21 & - & $32,41,44,46$ & 44 & $9,17,32$ & - \\
\hline 22 & - & - & 45 & - & $1,5,7,32,33,36,44$ \\
\hline 23 & - & - & 46 & - & - \\
\hline
\end{tabular}

- : Efficient 
The target values for economic properties of beekeeping enterprises according to input-oriented BCC method were shown in Table 2 . In the study, 31 of the beekeeping enterprises $(67 \%)$ were found to be efficient. The average efficiency value was calculated as 0.94 . Among the efficient enterprises, the one to give the most number of references (11 references) was the enterprise numbered 32 (Table 5). For example, the enterprise numbered 14 had to take enterprises numbered 1, 3, 4, 17, 23, and 32 as references to become efficient (Table 5). Accordingly, it could become efficient by reducing the cost of bee feeding by $1334 \mathrm{E}$, the cost of auxiliary material by $683 €$, the cost of marketing and packaging by 875 , the cost of transportation and hive accommodation by $2117 £$, the cost of the drug by $208 €$, the cost of other expenses by $415 €$ and maintenance-repair cost by $215 €$, and by increasing the income from honey sales by $7360 €$.

After the determination of the efficiency of beekeeping enterprises by DEA, the determination of parameters estimated to affect the efficiency scores were calculated using truncated regression analysis. The variables that effects the technical and economic properties efficiency scores of beekeeping enterprises and results were shown in Tables 3 and 4. It was determined that in terms of technical properties of enterprises, the owner's beekeeping experience $(\mathrm{P}<0.05)$, educational level $(\mathrm{P}<0.001)$, and the number of a colony $(\mathrm{P}<0.001)$ were in positive effect and had a statistically significant on efficiency scores, and race of bee $(\mathrm{P}<0.001)$ was in negative effect and had a statistically significant on efficiency scores (Table 3 ).

It was determined that, in terms of economic properties of enterprises, the influence of the owner's beekeeping experience $(\mathrm{P}>0.05)$ and record-keeping status $(\mathrm{P}>0.05)$ on efficiency scores of enterprises were in positive effect, but were not statistically significant. It was also determined that the influence of the enterprise owner's educational level $(\mathrm{P}>0.05)$, number of colonies $(\mathrm{P}>0.05)$, race of bee $(\mathrm{P}>0.05)$, frequency of changing the queen (changing the queen for more than 2 years) $(\mathrm{P}>0.05)$ was in negative effect and statistically non-significant on efficiency scores of enterprises (Table 4).

\section{Discussion and Conclusion}

In various studies carried out using DEA $(14,16,29)$, it was observed that the economic properties of enterprises were analyzed rather than their technical properties. It is quite important and instructive to analyze enterprises in terms of their technical properties along with economic parameters. Examining the technical properties of enterprises using DEA models has the characteristics of foresight for an enterprise that is planned to be started.

According to the DEA results of technical and economic properties of beekeeping enterprises, the enterprises which were shown as references the most are identified as number 7 and 32 by 11 times and number 32 by 11 times, respectively. Enterprise number 32 was said to use its technical and economic inputs more effectively compared to other enterprises. In different researches, reference sets were formed and it was reported that in order for the non-efficient decision making units to become efficient, they must resemble efficient decision making units $(1,4,14)$. The reference set that consists of efficient units is of great importance for the non-efficient units to reach their target values.

According to input-oriented BCC model results of technical and economic properties of beekeeping enterprises respectively 40 enterprises $(87 \%)$ and 31 enterprises (67\%) were found to be efficient. Efficient enterprises in different fields of livestock were determined using different DEA models (4, 14, 15, 23, 28). Accordingly, in terms of ease of interpretation and field feasibility, researchers are able to use whichever DEA model they want, without any obligation or conditions.

In the input-oriented BCC model for technical and economic properties of beekeeping enterprises, the average efficiency score was calculated as 0.97 and 0.94 , respectively. In a study conducted in Turkey on beekeeping (16), the researcher identified the technical efficiency score as 0.84 , and the economic efficiency score as 0.63 . The average efficiency scores in beekeeping enterprises were calculated as, 0.55 in Nigeria (3), as 0.89 in Ghana (2), as 0.57 in Greece (25), and as 0.85 in Adana (27). It was understood that, when compared to other studies, technical and economic efficiency scores were high. The reasons for this are thought to be the place of study, the difference between the input and output variables, different approaches about beekeeping in different countries and regions and the alteration of efficiency scores according to the applied DEA model.

In various studies about efficiency analysis, it was seen that regression models such as classical regression, Tobit regression and truncated regression were used in relation to analyzing parameters, which were considered to be influential on efficiency $(6,7,15,16,23,27,28)$. The experience of the enterprise owner, included in the study, was similar to the study in which its relation to efficiency was analyzed (2). It was not similar to the study by Olarinde et al. (26).

In the study, in terms of technical properties that the owner's experience was found significant, makes us think that he is experienced in matters such as following the beekeeping production and technology about breeding, and being open to any kind of scientific innovation about honey production. The reason why this did not reflect economic efficiency was thought to be that the input costs increase over time and that government support for beekeeping is not satisfactory enough. In our study, it was 
determined that, technically, colony number was a significant factor and had a positive effect on efficiency, that it was economically non-significant but had a negative effect. It was similar to studies $(12,16,27)$. It was considered that a rise in the number of colonies, will thus increase honey production and incidental incomes, namely the technical efficiency. Economically, however, it will not be quite possible to experience an increase in output amount for reasons such as that the honey sale price was not high in the market and the government support was not satisfactory, and besides that due to the increase in the number of colonies, input costs will considerably increase. In the study, it was seen that the race of bees was a technically significant factor in efficiency, but it was not economically significant. Technically, choosing race of bee which are compatible with the conditions in the area of beekeeping and which are able to adapt quickly makes a positive contribution. Though found to be economically non-significant, by the increase in the number of enterprises included in the research, it is expected that this variable will become significant.

Consequently, an efficient beekeeping enterprise technically must have hives between 180 and 200, between 30 and 50 kilograms of processed beeswax, between 2 and 7 sacks of sugar used for feeding bees, 1 staff, and between 30 and 45 cans to store honey. Economically, the cost of bee feeding should be between 500 and $2000 \mathrm{E}$, the cost of transportation and hive accommodation should be 500 and $2000 €$ and other expenses should be between 1000 and 1500 £. For Hatay province, crossbreed bee races should be used, enterprises should not use the queen bee for more than 2 years, and they must certainly produce bee products except honey. In order to promote efficiency in beekeeping enterprises, the beekeepers must manage the input use well. When producers produce beekeeping bee products as well as honey, their contribution both to the national economy and to their own economy will become even bigger. Enterprises, not only in the field of beekeeping but also in all sectors related to livestock, must be analyzed using data envelopment analysis, and the loss resulted from the wrong use of sources must be prevented by taking necessary precautions.

\section{Acknowledgements}

This manuscript is derived from the $\mathrm{PhD}$ thesis of the first author. We would like to thank The Turkish Association of Beekeepers (TAB) for their kindly help in field studies and coordination with the beekeeping enterprises.

\section{Finacial support}

This research received no grant from any funding agency/sector.

\section{Ethical Statement}

This study does not present any ethical concerns.

\section{Conflict of Interest}

The authors declared that there is no conflict of interest.

\section{References}

1. Abacioğlu S, Ünal İH (2017): Veri zarflama ve siral lojistik regresyon analizi ile şirketlerin etkinliklerinin belirlenmesi: Dokuma, giyim eşyası ve deri sektörü üzerine bir uygulama. ASEAD, 12, 1-19.

2. Abdul-Malik A, Mohammed A (2012): Technical efficiency of beekeeping farmers in Tolon-Kumbungu district of Northern region of Ghana. J Dev Agric Econ, $\mathbf{4}$, 304-310.

3. Aburime IL, Omotesho OA, Ibrahim HY (2006): An analysis of technical efficiency of beekeeping farms in Oyo state, Nigeria. Eur J Soc Sci, 4, 1-8.

4. Akçay A, Çelik E, Sarı̈̈zkan S (2017): Veri zarflama analizi ile koyunculuk işletmelerinin etkinliklerinin belirlenmesi: Yozgat ili örneği. 184-195. II. Ulusal Hayvancillk Ekonomisi Kongresi. Antalya, Turkey.

5. Banker RD, Charnes A, Cooper WW (1984). Some models for estimating technical and scale inefficiencies in data envelopment analysis. Manage Sci, 30, 1078-1092.

6. Barlovic N, Kezic J, Osmanagic Benedik N, et al (2009): Economic efficiency of beekeeping in Croatia. Agric Conspec Sci, 74, 51-54.

7. Ceyhan V, Canan S, Yıldırım Ç, et al (2017): Economic structure and services efficiency of Turkish Beekeepers' Association. Eur J Sustain Dev, 6, 53-64.

8. Charnes A, Cooper WW, Lewin AY, et al (1994): Data Envelopment Analysis: Theory, Methodology, and Application. Springer Science+Business Media, LLC, USA.

9. Cooper WW, Seiford LM, Tone K (2007): Data Envelopment Analysis - A Comprehensive Text with Models, Applications, References and DEA-Solver Software, Second Edition. Springer Science+Business Media, LLC, USA.

10. Çağlar A (2003): Veri zarflama analizi ile belediyelerin etkinlik ölçümü. Doktora Tezi, Hacettepe Üniversitesi Fen Bilimleri Enstitüsü, Ankara.

11. Çevrimli MB, Sakarya E (2018): Arıcllık işletmelerinin yapısal özellikleri ve sorunlart; Ege Bölgesi örneği. Eurasian J Vet Sci, 34, 83-91.

12. Çevrimli MB (2019): Assessment of the effects of subsidies to the beekeeping sector in Turkey on the number of hives and amount of honey produced. Vet Hekim Der Derg, 90, 115-121.

13. Çevrimli MB, Sakarya E (2019): Economic analysis of beekeeping enterprises in Aegean Region, Turkey. Ankara Univ Vet Fak Derg, 66, 109-115.

14. Demir P, Derbentli Ö, Sakarya E (2012): Kars ilinde bulunan mandıraların etkinliğinin veri zarflama analizi ile ölçülmesi. Kafkas Univ Vet Fak Derg, 18, 169-176.

15. Doğan N (2017): Konya ilinde yumurta tavukçuluğu yapan işletmelerin teknik ve ekonomik analizi. Doktora Tezi, İstanbul Üniversitesi Sağlık Bilimleri Enstitüsü, İstanbul. 
16. Emir M (2015): Türkiye'de arıcıların sosyo-ekonomik yapısı ve üretim etkinliği. Doktora Tezi, Ondokuz Mayıs Üniversitesi Fen Bilimleri Enstitüsü, Samsun.

17. FAO (2017): Food and Agricultural Organization, Animal production. Available at: http://www.fao.org/faostat/ en/\#data. (Accessed December 10, 2019).

18. Fernandes FDS, Stasinakis C, Bardarova V (2018): Twostage DEA-Truncated Regression: Application in banking efficiency and financial development. Expert Syst Appl, 96, 284-301.

19. Firatlı Ç, Gençer HV (1995): Dünya Arıcılığı ve Türkiye'nin Yeri. TC Ziraat Bankası Kültür Yayınları, No:28, Ankara, Turkey.

20. Fıratlı Ç, Karacaoğlu M, Gençer HV, et al (2010): Türkiye arıcılığının yapısal analizi. TMMOB Ziraat Mühendisleri Odas1, Türkiye Ziraat Mühendisliği VI. Teknik Kongresi, Ankara, Turkey.

21. Gören KB (2012): Veri zarflama analizi ile kanola bitkisinin üretim maliyetleri ve ekonomik verimliliğinin ölçülmesi. Yüksek Lisans Tezi, Trakya Üniversitesi Sosyal Bilimleri Enstitüsü, Edirne.

22. Kai D, Worthington AC, Zelenyuk V (2018): Data envelopment analysis, truncated regression and doublebootstrap for panel data with application to Chinese banking. Eur J Oper Res, 265, 748-764.

23. Kaygısız F, Evren A, Koçak Ö, et al (2018): İstanbul'un Çatalca ilçesindeki mandacılık işletmelerinin etkinlik analizi. Ankara Univ Vet Fak Derg, 65, 291-296.

24. Kirigia JM, Emrouznejad A, Sambo LG, et al (2004): Using data envelopment analysis to measure the technical efficiency of public health centers in Kenya. J Med Syst, 28, 155-166.

25. Makri P, Papanagiotou P, Papanagiotou E (2015): Efficieny and economic analysis of Greek beekeeping farms. Bulg J Agric Sci, 21, 479-484.
26. Olarinde LO, Ajao AO, Okunola SO (2008): Determinants of technical efficiency in bee-keeping farms in Oyo state, Nigeria: A stochastic production frontier approach. Res J Agric Biol Sci, 4, 65-69.

27. Ören MN, Alemdar T, Parlakay O, et al (2010): Adana İlinde Arıcılık Faaliyetinin Ekonomik Analizi. Yayın no: 178. Tarımsal Ekonomi Araştırma Enstitüsü, Ankara.

28. Özden A (2016): Veri zarflama analizi ile süt siğırcılı̆̆ işletmelerinin performans düzeylerinin belirlenmesi. Tarım Ekonomisi Dergisi, 22, 49-55.

29. Ritten CJ, Peck D, Ehmke M, et al (2018): Firm efficiency and retuns-to-scale in the honey bee pollination services industry. J Econ Entomol, 111, 1014-1022.

30. Sarı Z (2015): Veri zarflama analizi ve bir uygulama. Yüksek Lisans Tezi, Hacettepe Üniversitesi Fen Bilimleri Enstitüsü, Ankara.

31. Sarı̈zkan S, İnci A, Yıldırım A, et al (2009): Kapadokya'da arıcilı. Erciyes Univ Vet Fak Derg, 6, 143155.

32. Simar L, Wilson $\mathbf{P}$ (2007): Estimation and inference in two-stage semiparametric models of production processes. J Econom, 136, 31-64.

33. Sümbüloğlu K, Sümbüloğlu V (1997): Örnekleme Yöntemleri. Hatipoğlu Yayınevi, Ankara.

34. Şener C (2013): Veri zarflama analizi ve Malmquist endeksi ile Avrupa Birliği ülkelerinin sağllk performanslarının incelenmesi. Yüksek Lisans Tezi, Gazi Üniversitesi Fen Bilimleri Enstitüsü, Ankara.

35. TÜİK (2018): Arıcıllk verileri. Available at: http://www.tuik.gov.tr/Start.do. (Accessed November 10, 2019).

36. Yeninar H, Akyol E, Şahinler N, et al (2010): Taşıma ve çevre şartlarının gezginci arıcılık koşullarında, bal arısı kolonileri üzerine etkilerinin belirlenerek uygun taşımacılık ve kışlama yöntemlerinin geliştirilmesi. Available at: https://app.trdizin.gov.tr/publication/show/pdf/project/TV RBMU5qRXg. (Accessed October 12, 2020). 